\title{
KIEROWNIK PROJEKTU INFORMATYCZNEGO I JEGO ROLA W ZESPOLE REALIZUJACCYM PROJEKT
}

\author{
JERZY KISIELNICKI ${ }^{1}$ \\ Uniwersytet Warszawski \\ Wydział Zarządzania \\ ${ }^{1}$ e-mail: jkisielnicki@wz.uw.edu.pl
}

SŁOWA KLUCZOWE

STRESZCZENIE zarządzanie projektami informatycznymi, kierownik projektu, metodyka projektowa, project manager

W artykule zostały przedstawione wybrane problemy dotyczące analizy roli kierownika projektu informatycznego. Celem artykułu jest identyfikacja zbioru wymagań, jakie należy stawiać kierownikowi projektu informatycznego. Wychodzi się tu z założenia, iż kierownik tego typu projektu jest zarówno menedżerem, jak i twórcą, który realizuje unikalne przedsięwzięcie - projekt informatyczny. Wymagania zostały określone na podstawie analizy literatury przedmiotu, jak i prowadzonych własnych badań w trakcie realizacji dużych projektów informatycznych oraz badań opinii słuchaczy studiów podyplomowych, w tym studiów MBA. Przedstawiono również propozycje badań przyszłościowych.

\section{Wprowadzenie}

Specyfika zarządzania projektami informatycznymi to działanie w stale zmieniającym się otoczeniu, gdzie podejmowane decyzje są obarczone dużym ryzykiem. Projekty informatyczne możemy zaliczyć do klasy projektów badawczo-rozwojowych. Podobnie jak w nich, zarządzając, musimy brać pod uwagę zmiany wywołane postępem technicznym i technologicznym. W zarządzaniu projektami informatycznymi kierownik projektu powinien przestrzegać pewnych zasad, 
które nie występowały z taką siłą w zarządzaniu klasycznym. Do nich możemy zaliczyć między nimi:

1. zmienność sytuacji oraz konieczność stałych modyfikacji założeń i zachowań,

2. pracę $\mathrm{w}$ określonych przedziałach czasowych (dylemat pracy stabilnej czy w pewnym stopniu niepewnej).

W konsekwencji możemy postawić tezę, iż kwalifikacje sprawnego menedżera to za mało dla kierowania projektem informatycznym. Należy być również twórczym. Zwymiarowanie pojęcia twórczy w kontekście kierowania projektem informatycznym jest naszym zadaniem.

Celem artykułu jest identyfikacja zbioru wymagań, jakie należy stawiać kierownikowi projektu informatycznego. Wychodzi się tu z założenia, iż kierownik tego typu projektu jest zarówno menedżerem, jak i twórcą, który realizuje unikalne przedsięwzięcie, jakim jest najczęściej projekt informatyczny. Zbiór wymagań został określony na podstawie analizy literatury i prowadzonych własnych badań.

Zarządzanie i praca w realizacji projektów niosą ze sobą wiele różnorodnych wyzwań. Wiele współczesnych projektów powstaje w środowiskach wielokulturowych. Tradycyjne procedury: zarządzania, rekrutacji, selekcji, rozwiązywania sytuacji konfliktowych, zarządzania kompetencjami i talentami wymagają nieco innego spojrzenia. Projekt informatyczny musimy zakończyć w określonym czasie, zdając sobie sprawę, że na początku jego realizacji nie wszystko jest do końca określone. Uściślenie jego parametrów następuje często dopiero $\mathrm{w}$ trakcie realizacji.

Zarządzanie projektami informatycznymi określamy jako zespół logicznie uporządkowanych czynności, które nie są do końca zdefiniowane, a niekiedy tylko zarysowane. Dlatego możemy zaobserwować rozwój zwinnych metodyk w realizacji projektów informatycznych. W tego typu projektach przed ich kierownikami staje zadanie doprecyzowania celu, które dokonuje się w trakcie prowadzonych prac.

W artykule problematyka zarządzania projektami informatycznymi analizowana jest z punktu widzenia zarówno teorii, jak i praktyki.

Część teoretyczna to propozycje autora, które wynikają z własnych przemyśleń i doświadczeń oraz wniosków wyciągniętych z analizy literatury przedmiotu.

Część praktyczna to analiza:

- systemu zarządzania i roli kierownika w realizowanych przez autora dużych projektach badawczo-rozwojowych, w których pełnił on funkcje lidera i wykonawcy,

- materiałów pochodzących z dyskusji i badań ankietowych prowadzonych na studiach podyplomowych z zakresu projektowania oraz na sympozjach polskiego oddziału IPMA,

- projektów realizowanych na studiach podyplomowych, a szczególnie studiach MBA prowadzonych pod kierownictwem autora.

Prezentowane wyniki jakościowych badań nad wymaganiami stawianym kierownikom projektów informatycznych są etapem do pogłębionych badań ilościowych nad wpływem tych wymagań na efektywność realizacji projektu. Ciekawym, ale tylko zasygnalizowanym proble- 
mem jest określenie zależności między wymaganiami a rodzajem stosowanej metodyki realizacji projektu.

\section{Kierownik projektu informatycznego i jego kwalifikkacje}

Rola kierownika (Project manager, Project leader) łączy się z pojęciem władzy. Dla wielu ludzi władza jest ważniejsza niż inne dobra. Sukces projektu zależy w dużej mierze od administracyjnej władzy kierowników. Właśnie ona warunkuje szybkość, elastyczność i przede wszystkim zysk w świecie konkurencji. Jednak władza ta, jak każda, niesie niebezpieczeństwo nadużyć. W świecie biznesu patologie w tym zakresie na szczęście występują rzadko, natomiast dość często (za często) występują w świecie polityki. Obecnie panuje powszechne przekonanie, iż sposobem na osiągnięcie sprawnego stosowania władzy jest używanie jej. Jak piszą Krzakiewicz i Cyfert (2012), w nowej rzeczywistości potrzebni są kierownicy - liderzy sensualni, którzy umieją odczuć zachowania swoich pracowników i umieją skłonić ich do ciągłej nauki i efektywnej pracy ${ }^{1}$.

Kierownik projektu jest odpowiedzialny za osiągnięcie założonych celów. Jego kluczowe obowiązki w procesie zarządzania projektami to m.in. stworzenie jasnych i osiągalnych celów, budowanie wymagań i zarządzanie zgodne z wymienionymi wcześniej zasadami trójkąta zarządzania projektami: kosztami, czasem, zakresem (w tym jakością). Kierownika projektu cechuje umiejętność dostosowania się do różnych sytuacji jego realizacji a także do budowy zespołu realizującego i tworzenia w nim bliskich i przyjacielskich więzi. Termin i tytuł kierownik projektu powinien być używany w stosunku do osoby, która ma: pełną odpowiedzialność i taki poziom władzy, który jest niezbędny do realizacji i ukończenia określonego projektu informatycznego. Jeśli dana osoba ich nie posiada, wtedy używa się określeń: administrator projektu, koordynator, pomocnik. Jeszcze do niedawna ludzie stawali się kierownikami projektu tylko dlatego, że przydzielano im takie obowiązki. Dziś kierownik projektu powinien stanowić o wartości kapitału intelektualnego projektu. Zarządzanie projektami łączy w sobie najważniejsze wymiary skutecznego prowadzenia działań badawczo-rozwojowych czy jakiejkolwiek innej działalności nastawionej na maksymalizowanie sukcesu prowadzonych operacji. Zawiera w sobie przedstawione wcześniej elementy, takie jak: zarządzanie ryzykiem, zarządzanie wiedzą, planowanie, zarządzanie jakością, kosztorysowanie, obejmuje tzw. miękkie i twarde metody zarządzania, akcentując role relacji międzyludzkich w realizacji procesów pracy (zarządzania zespołem i skutecznej komunikacji). Dzięki temu otrzymujemy kompletne narzędzie pozwalające na skuteczne kontrolowanie wszystkich procesów realizowanych przedsięwzięć.

$\mathrm{Na}$ większości uczelni uniwersyteckich i politechnicznych są specjalizacje kształcące specjalistów od zarządzania projektami. Są to studia ogólne. Równocześnie istnieją specjalistyczne studia podyplomowe. Dyplom kierownika projektu uzyskuje się również poprzez specjalistyczne

1 Sensualizm (z łac. sensus - zmysł) to pogląd filozoficzny głoszący, że wszelka wiedza pochodzi od wrażeń zmysłowych (poznanie odbywa się poprzez przeprowadzanie logicznych doświadczeń) i jest tylko bardziej lub mniej złożonym kompleksem spostrzeżeń. 
szkolenia prowadzone między innymi przez polski oddział IPMA, jak też przez Instytut Zarządzania Projektem. Wymagania formalne są następujące: dyplom ukończenia studiów (przynajmniej licencjackich, czyli pierwszego stopnia) oraz 4500 godzin praktyki zawodowej (3 lata). Kierownik projektu powinien posiadać wiedzę z zakresu dziedziny, w której realizuje projekt. Najczęściej wymienia się następujące jego cechy osobowe: zdolność do analizy, umiejętności zarządzania i współpracy z ludźmi, komunikatywność, odporność na stres, kreatywność, chęć stałego uczenia się, systematyczność, dyspozycyjność, a także umiejętność planowania i motywowania pracowników. Praca kierownika projektu informatycznego wymaga: wszechstronności, samodyscypliny, profesjonalizmu i ciągłej aktualizacji posiadanej wiedzy.

Praca kierownika projektu ma wiele cech wspólnych z pracą typowego kierownika zespołu funkcjonującego w tradycyjnej organizacji. Jego praca różni się jednak od tradycyjnego kierowania organizacją w kilku zasadniczych kwestiach. Przede wszystkim kierownik projektu realizuje pewne określone, niepowtarzalne przedsięwzięcie, do którego angażuje się tymczasową grupę roboczą. Po jego wykonaniu zespół najczęściej ulega likwidacji a pracownicy przechodzą do innych prac i obejmują nowe stanowiska. Pracownicy są rekrutowani z organizacji, która jest zainteresowana wynikami projektu lub też z innych organizacji, często poprzez działalność komórek rekrutacyjnych różnych organizacji. Celem projektu informatycznego jest stworzenie czegoś nowego, czegoś niepowtarzalnego. Dlatego też do realizacji wyznaczonych celów konieczna jest bardzo dobra współpraca między zleceniodawcą, zleceniobiorcą i beneficjentem projektu. Tak więc kierownik projektu winien być zarówno politykiem, jak i negocjatorem. Czy przedstawione wcześniej wymagania w stosunku do kierownika projektów informatycznych wyczerpuje listę postulowanych jego cech? Jakie cechy powinien mieć kierownik projektu? Takie pytania zadawałem w prowadzonych badaniach wśród słuchaczy studiów podyplomowych i to zarówno na studiach typu MBA - zarządzanie, MBA - HR, jak i na studiach dotyczących zarządzania projektami. Badania ankietowe polegały na tym, że słuchacze mieli za zadanie podać jedną dominującą cechę. Dla niektórych grup badanych słuchaczy (mających małe doświadczenie w pracy w zespołach projektowych) pytanie to było zmodyfikowane i brzmiało: Jakie cechy powinien mieć Twój szef, kierujący projektem?

Większość słuchaczy (ponad 80\%) odpowiadała, że dobry kierownik projektu to człowiek mądry i kompetentny, który jest liderem/przywódcą. Oczywiście podział nie jest dychotomiczny, ale można przyjąć, że to są cechy wzorcowego kierownika projektu. Czy wystarczające? Zależy co rozumie się pod tymi pojęciami. Rozumienie tego terminu było określane przez słuchaczy jako:

1. Mądrość to jest posiadanie odpowiedniej wiedzy i umiejętność jej wykorzystania w procesie decyzyjnym, tak aby wszyscy zainteresowani uzyskali korzyści.

2. Kompetencje to zdolność do kierowania zespołem realizatorów tak, aby zrealizować projekt w wyznaczonym zakresie, przy założonych nakładach i w założonym czasie.

W dyskusjach podkreślano, iż należy pamiętać o szczególnej roli kierownika projektu w utrzymaniu zespołu. Istnieje bowiem sytuacja, którą można określić jako podążanie za liderem (Follow the leader). Odejście lidera to bardzo często odejście od projektu najbliższych jego 
współpracowników. W przywołaniu kluczowych kompetencji kierownika projektu pomocna może być również metodyka PRINCE2 wskazująca, iż są one związane przede wszystkim z: planowaniem, zarządzaniem czasem, zarządzaniem personelem, rozwiązywaniem problemów, skrupulatnością, zarządzaniem konfliktami, z komunikacją i negocjacjami.

\section{Kierownik projelkitu i jego rola w zespole}

Kierownik projektu, aby skutecznie i efektywnie zarządzać zespołem realizatorów, musi posiadać środki i władzę. Szaban (2003) dzieli władzę ze względu na jej pochodzenie na:

- władzę legitymistyczną - wywodzącą się z przekonania, że sprawującego władzę po prostu trzeba słuchać, bo ma on legitymację do jej sprawowania.

- władzę tradycyjną - wynikającą z obyczajów nie zawsze zapisanych w regulaminie pracy i innych aktach prawnych,

- władzę ekspercką - gdy słucha się kogoś ze względu na jego wiedzę i umiejętności, dzięki którym sprawuje władzę nad innymi.

- władzę charyzmatyczną - wynikającą z określonych przymiotów osoby sprawującej władzę, takich jak: posiadanie wizji, idea i potrzeba zmian, mającej przyciągający uwagę styl bycia.

Kierownik projektu informatycznego powinien posiadać wszystkie wymienione rodzaje władzy, ale uważam, iż najbardziej istotna jest władza ekspercka i charyzmatyczna. Przywódców charyzmatycznych niekiedy określamy mianem przywódców transformacyjnych. Tacy przewódcy powinni posiadać też takie cechy jak: inteligencja, umiejętności społeczne, dar przekonywania, skłonność do dominacji, ambicja, asertywność. Użycie pojęcia przywódca transformacyjny ma na celu podkreślenie, że rola kierownika projektu, polega na: inspirowaniu, wytyczaniu nowych ambitnych celów, motywowaniu ludzi do ich realizacji, zdolności podejmowania decyzji. Realizacja każdego projektu informatycznego stanowi pewną niewiadomą, a jego realizacja wymaga dużej odwagi. Kierownik projektu jest osobą, która ma świadomość, że nie wszystko można przewidzieć, że zarządzanie projektem związane jest z ryzykiem utraty pozycji zawodowej, kompromitacji. Kierownik projektu powinien być szkolony na czasy kryzysowe, w nich bowiem ma szanse pokazania swojej charyzmy i kwalifikacji.

Niekiedy zamiast określenia kierownik projektu używamy terminu lider projektu - wtedy, kiedy chcemy powiedzieć, że ludzie taką osobę naśladują oraz poddają się jej przywództwu. W literaturze kierowników zespołów w ramach projektu nazywa się też liderami strumieni projektowych. I tak Merton (1985) dokonał następującego rozróżnienia wśród kierowników projektów:

- ludzie, którzy wywierają wpływ na zespół w chwili obecnej, a ich pozycja społeczna jest ustalona,

- ludzie potencjalnie wpływowi (wschodzące gwiazdy, pnące się do górę po drabinie społecznej), 
- ludzie, których wpływ stopniowo zanika (po osiągnięciu szczytu przesuwają się w dół drabiny społecznej),

- ludzie, których wpływ jest ukryty (osoby te posiadają obiektywne cechy osoby wywierającej wpływ, ale nie wykorzystują tej właściwości).

Stosując tę typologię, możemy stwierdzić, że kierownik projektu należy do dwóch pierwszych grup ludzi. Kierownik projektu jest zwierzchnikiem zespołu realizującego projekt. Według Schelle i współpracowników (2006) kierownik projektu to człowiek: odpowiedzialny za realizację projektu, organizuje zespół i odpowiada za zarządzanie, planowanie i monitorowanie projektu. Jednym z najbardziej istotnych stawianych mu wymagań jest posiadanie autorytetu. Jego istotne zadanie polega na stworzeniu warunków do osiągnięcia postawionego przed zespołem celu lub celów. Zadania i usługi wykonywane przez kierownika projektu są inne od tych, które wykonują pozostali członkowie zespołu realizującego projekt. Kierownik projektu kieruje pracą innych i również za nią odpowiada. Wykonuje on także zadania, kiedy instruuje, naucza czy udziela wskazówek. W ten sposób rozwija umiejętności pracowników. Relacje kierownik - pracownicy to w zasadzie relacje couch (trener) - zawodnicy. Trener, który dzieli się swoim doświadczeniem z osoba, którą szkoli.

Mintzberg (1994) opracował system, który nawet po wielu latach jest określany jako: role kierownicze według Mintzberga. Według tego systemu wszyscy kierownicy realizujący projekt odgrywają w nim trojaką rolę, a mianowicie:

- interpersonalną,

- informacyjną,

- decyzyjną.

Kierownik w ramach odgrywania roli interpersonalnej, nazywanej często rolą międzyludzką, odgrywa także rolę reprezentacyjna, a więc do jego zadań należy witanie gości, branie udziału w spotkaniach i uroczystościach zewnętrznych, reprezentowanie organizacji, wygłaszanie przemówień okolicznościowych, udzielanie wywiadów, branie udziału w kontaktach z ludźmi z zewnątrz.

Rola informacyjna polega na tym, że kierownik zbiera i rozpowszechnia informacje. W tym zakresie:

- monitoruje pracę zespołu i zachowania się tego zespołu, kierownik projektu powinien być najlepiej poinformowanym członkiem grupy,

- jest rzecznikiem i przekazuje oficjalne informacje o projekcie osobom spoza organizacji, przykładowo bankom, mediom.

Trzecia rola, która jest najbardziej istotna z punktu widzenia zarządzania każdym projektem, to rola decyzyjna. W tym zakresie możemy określić następujące rolę wszystkich kierowników projektu:

- działanie na rzecz udoskonalenia projektu,

- przeciwdziałanie zakłóceniom i w miarę możliwości zmniejszanie negatywnych skutków sytuacji, które są poza jego działaniem, 
- alokacja zasobów potrzebnych do osiągnięcia założonych celów, rozwiazywanie sytuacji konfliktowych.

Wykonanie tych funkcji wymaga posiadania następujących trzech podstawowych rodzajów umiejętności: technicznych, społecznych, koncepcyjnych.

Umiejętności techniczne to zdolność posługiwania się narzędziami, metodami i technologią.

Umiejętności społeczne to zdolność współpracy z innymi ludźmi, i to zarówno z poszczególnymi osobami, jak i z grupami.

Umiejętności koncepcyjne to zdolność do koordynacji działań poszczególnych grup realizatorów oraz integrowanie wszystkich działań realizowanych w jego polu działania. Istotną umiejętnością jest monitoring otoczenia, czyli wychwytywanie słabych sygnałów o możliwościach i zagrożeniach w realizacji projektu.

Kierownik projektu realizuje zadania w ramach ciągle zmieniającej się sytuacji zarówno wewnętrznej, jak i zewnętrznej. Wykorzystuje przy tym teorie nauk zarządzania, takie jak: zarządzanie naukowe, zarządzanie behawioralne, w tym psychologię pracy, oraz zarządzanie systemowe. Stosowanie łącznie wszystkich podejść dla rozwiązania konkretnego problemu określa się jako zarządzanie zintegrowane. Kierownik projektu musi być wyczulony na to, aby stworzyć sprzyjające warunki, w których realizuje się projekt jak najbardziej wydajnie. W większości przypadków pracownik pracuje, aby zaspokoić określone potrzeby. Kierownik projektu, znając potrzeby pracowników i wiedząc, które z nich są zaspokajane, a które jeszcze nie, może stworzyć warunki do motywacyjnego zachowania pracowników. Minimum umiejętności kierowniczych to: inteligencja, odporność psychiczna i określony poziom moralny, a także pewien zespół predyspozycji nazywanych talentem kierowniczym czy zmysłem organizacyjnym (por. Kieżun, 1997). Jak podkreśla Romanowska (2001), obecnie kształtuje się nowy profil kierownika. Złożoność problematyki zarządzania powoduje znaczący wzrost stawianych mu wymagań. Ta nowa sytuacja powoduje, że sprostanie rosnącym trudnościom wymaga wzrostu umiejętności i kompetencji kierowników i innego niż w systemach tradycyjnych odgrywania przez nich ról kierowniczych. Jak pisze Jabłoński (2009), współczesne koncepcje zarządzania charakteryzują się rezygnacją z posługiwania się pojęciami: kwalifikacje, uzdolnienia i zastępują je pojęciem kompetencji.

W warunkach realizacji projektów w ramach tzw. programów ramowych dofinansowanych ze środków Unii Europejskiej należy zwrócić uwagę na aspekty umiędzynarodowienia zarządzania, co wymaga od kierownika projektu pracującego bardzo często w międzynarodowej grupie konieczności dostosowania się do określonych wymagań kulturowych.

Kierownik projektu ma do rozwiązania bardzo różne problemy. Między innymi bardzo często staje przed dylematami takimi jak lojalność i etyka. Większość kierowników projektu wysoko ceni lojalność swoich podwładnych. Lojalność może być również postrzegana jako stosowanie zasad wynikających z tzw. społecznej odpowiedzialności biznesu, a w tym: między innymi posłuszeństwa, wysiłku, wiarygodności i skuteczności działań, ochrony, uczciwości, etyki. 
Zwracamy uwagę, że rozumie się tu pojęcie społecznej odpowiedzialności biznesu nie tylko jako zagadnienie zewnętrzne w projekcie, ale również wewnętrzne.

\section{Budowa zespotu realizującego projekt}

Przyporządkowanie poszczególnych osób do odpowiednich zadań jest podstawą polityki zarządzania zespołem. Budowa zespołu jest najtrudniejszym i jednym z najodpowiedzialniejszych zadań kierownika projektu. Cały czas należy pamiętać, że zasoby ludzkie (kapitał intelektualny) tym przede wszystkim różnią się od innych zasobów organizacji, że można je szybko stracić. Pozyskiwanie odpowiednich ludzi oraz tworzenie warunków skłaniających ich do aktywnego uczestnictwa w realizacji projektu jest trudne.

Analiza europejskiego rynku pracy (maj 2016) pokazuje, że popyt na informatyków znacząco przeważa nad podażą. Informatycy dobrze wykształceni są poszukiwani nie tylko w kraju, ale i zagranicą. Szczególnie dotyczy to Niemiec i Austrii. Zakres i sposób angażowania personelu zależą od: wielkości i rodzaju projektu informatycznego i jego innowacyjności, sytuacji na rynku pracy oraz stylu zarządzania przyjętego przez kierownika projektu, jak i innych kierowników lub twórców a także sponsorów. Wypełnieniem struktury organizacji jest zatrudnienie właściwych ludzi we właściwym czasie do realizacji projektu. W sytuacji kiedy nie budujemy zespołów od nowa, ale posiadamy już wcześniej zaangażowanych ludzi, należy przygotować, a następnie wdrożyć programy planowania działań, które powinny zapewnić eliminację różnic między stanem pożądanym a istniejącym oraz uwzględniać konieczność zsynchronizowania alokacji zasobów pomiędzy zamykanymi i uruchamianymi projektami. Ponieważ przesunięcia te nie są realizowane w relacji 1:1, stąd członkowie zespołów projektowych często stają się sukcesorami dla osób z formalnej struktury organizacyjnej. Niejednokrotnie zjawisko to ma miejsce przed zakończeniem realizacji projektu, co w sposób naturalny stawia przed kierownikiem projektu kolejne rekrutacyjne wyzwania.

Jak pisze Gregorczyk i współpracownicy (2004), sposób rekrutacji i doboru pracowników uzależniony jest od wielu czynników. Można zaliczyć do nich: specyfikę przedsięwzięcia, technologię jego realizacji, stopień złożoności, wymagania wynikające ze specyfiki danej dziedziny działalności, pożądany kształt zespołu projektowego i warunki, w jakich będzie pracował zespół. W przypadku kompletowania zespołu projektowego wykorzystuje się rekrutację zamkniętą do ograniczonego z góry zbioru kandydatów. W procedurze selekcji kandydatów, którzy zgłosili się w procesie rekrutacji, dąży się do uzyskania jak najmniejszych różnic pomiędzy określonymi na wstępie wymaganiami a tymi, które reprezentuje kandydat. Jak podkreślają w przeprowadzonych badaniach ankietowych słuchacze studiów MBA (którzy w większości są pracodawcami), nie poszukuje się kandydata najlepszego, ale takiego, który w największym stopniu spełnia oczekiwania wynikające z przygotowanego uprzednio opisu stanowiska pracy i profilu cech osobowych członka zespołu. Badania realizowane były w okresie 2014-2016 na studiach podyplomowych i MBA na zbiorze ok. 120 uczestników. 
Na etapie rekrutacji i selekcji członków zespołu projektowego popełnianych jest wiele błędów. Najczęstsze z nich według badań ankietowych to:

- delegowanie do zespołu osób, które są niepotrzebne w macierzystych komórkach organizacyjnych, ale trzeba im znaleźć jakieś zadanie;

- delegowanie do pracy dobrych specjalistów, lecz takich, którzy mają już inne zadania, co prowadzi do konfliktu;

- obsadzenie kluczowych stanowisk według znajomości, a nie według kompetencji pracowników;

- brak dyscypliny na etapie selekcji i włączenie do zespołu zbyt wielu osób zamiast minimalnego grona potrzebnego do wykonania pracy.

Proces organizowania zatrudnienia personelu do realizacji projektu jest procesem iteracyjnym, składającym się z następujących etapów:

1. Analizowanie potrzeb napodstawie:zadań projektu, harmonogramu realizacjiposiadanych baz danych kadrowych oraz doświadczeń organizacji z realizacji poprzednich projektów.

2. Określenie profili potrzebnych do realizacji projektu pracowników przez kierownika projektu.

3. Tworzenie planów i programów działania w zakresie obsady, oceny, wynagradzania i rozwoju personelu.

4. Kontrola i ocena proponowanych planów i programów rekrutacji.

Jak uważają pracownicy działów HR, pytani o sytuację na rynku pracy w Warszawie, poszukiwanie pracowników do pracy w projektach informatycznych jest - ze względu na wysokie wymagania i płytki rynek pracy - trudniejsze niż do innych rodzajów projektu. Kiedy tworzymy zespół do realizacji projektu, musimy skompletować grupę ludzi, którzy posiadają:

- kompetencje potrzebne do realizacji zadań,

- predyspozycje do pełnienia określonych funkcji.

Są one istotne, ale jak wykazuje praktyka i przeprowadzone analizy, ważniejsze są te drugie. Mylne jest bowiem ocenianie pracownika tylko na podstawie jego formalnych dokumentów, np. certyfikatów IPMA Polska lub PMI. Bardzo często okazuje się, że świetnymi członkami zespołu są ci pracownicy, których kompetencje formalne częściowo tylko odpowiadają stawianym im wymaganiom.

Dlatego dobrze jest, aby rekrutowany zespół zachowywał tzw. wewnętrzną równowagę. Jak wykazuje i moja praktyka, lepsze jest tworzenie początkowo niewielkiego zespołu, a następnie dokooptowanie nowych ludzi. Wtedy kierownik projektu wie, kogo mu jeszcze potrzeba i jakie ten ktoś powinien posiadać kwalifikacje. Trzeba pamiętać o naturalnej dynamice rozwoju zespołu projektowego. Kierownik projektu, rekrutując pracownika, który jest bardzo dobry na początku realizacji zadania, musi zdawać sobie sprawę, że później tak nie musi być. Uważam, iż najczęstszym błędem popełnianym w procesie rekrutacji jest przekonanie osoby odpowiadającej za ten proces, że jedynym słusznym narzędziem, jakim się ona posługuje, jest jej doświadczenie i intuicja. Kluczowym problemem w procesie rekrutacji jest zrozumienie i uwzględnienie potrzeb projektu oraz identyfikacja sposobu myślenia i działania, przekonań, hierarchii wartości, 
osobowości, interesów czy temperamentu kandydatów. Działy kadrowe powinny być w procesach rekrutacji pracowników bardzo aktywne, zaś kierownik zespołu winien bezwzględnie pamiętać, że jego sukces zależy m.in. od sukcesu rekrutacyjnego członków zespołu projektowego, stąd konieczna jest ścisła współpraca kierownika projektu z osobami rekrutującymi oraz określenie przez niego kluczowych kwalifikacji i kompetencji wymaganych od poszczególnych kandydatów na członków tego zespołu.

Ramowy schemat postępowania angażowania zespołu do realizacji projektu badawczego SIR (System Informatyczny Rachunkowości), który stosowany był przez autora, przedstawiony został w monografii (Kisielnicki, 2013). Projekt był realizowany w CPIZI ZETO-ZOWAR (Centrum Projektowania i Zastosowań Informatyki) dla Ministerstwa Finansów. Projekt miał na celu pierwsze w Polsce zastosowanie systemu informatycznego w obszarze rachunkowości (analiza bilansu) w przedsiębiorstwie Elana Toruń.

Pozyskanie dobrego pracownika do zespołu projektowego to nie wszystko. Ważne jest to, aby go nie stracić. Rozszerzając tematykę rekrutacji, zwraca się uwagę na etap wprowadzenia pracownika do pracy. Osoby przyjęte do pracy odczuwają napięcie związane z koniecznością przystosowania się do nowego środowiska. W konsekwencji takiej postawy część nowo przyjętych pracowników opuszcza nową pracę po kilku miesiącach. Celem programów wprowadzających jest redukcja stresu wynikającego z tych okoliczności. Rekomendowane jest dostarczenie nowemu pracownikowi trzech rodzajów informacji:

- ogólnych informacji o codziennej, rutynowej pracy,

- przeglądu historii powstania projektu i jego celów,

- danych szczegółowych (niekiedy w postaci broszury, wyciągów z umów handlowych lub umów wewnątrzkorporacyjnych) o zasadach obowiązujących w zespołach projektowych, ich regulaminie i świadczeniach przysługujących zatrudnionym.

W realizacji dużych projektów o zasięgu krajowym czy też globalnym rekomendowane jest realizowanie pod kierunkiem project managera tak zwanego programu wprowadzającego Pierwsze doświadczenia w pracy odgrywają rozstrzygającą rolę w kształtowaniu się nastawienia pracownika do organizacji, w której został zatrudniony, oraz do wykonywanych obowiązków. Przyjęcie do pracy jest momentem zderzenia się rzeczywistych oczekiwań pracownika z oczekiwaniami organizacji. Najwyższy wskaźnik fluktuacji kadr występuje właśnie wśród nowo przyjętych pracowników. Doświadczenie wykazuje, że pierwsze dni pracy mają znaczenie dla dalszej kariery danej osoby. Osoby, którym od początku przydzielano wymagające zadania, przyswajały sobie wysokie normy efektywności. Te natomiast, które otrzymywały łatwiejsze zadania, miały mniejszą motywację do wysokiej efektywności. Kariera tych pierwszych przebiegała szybciej, okazali się oni bowiem lepiej przygotowani do przyjęcia nowych obowiązków. Problematyka ta jednak wychodzi poza nakreślone ramy artykułu. 


\section{Zadania kierownika projektitu w konsolidaciji zespotu realizującego projektit}

Po stworzeniu zespołu społecznej odpowiedzialności biznesu do realizacji projektu, następnym krokiem jest scementowanie, czyli stworzenie skutecznego i efektywnego zespołu. Jak pisze Betta (2012): gdyby zadać kierownikowi projektu pytanie: Jak scharakteryzowałbyś idealnego członka zespotu projektowego?, odpowiedź brzmiałaby najprawdopodobniej tak: winien on całkowicie poświęcić się projektowi (najlepiej dyspozycyjność 24 godziny na dobę), cechować się inteligencją i zdrowym rozsądkiem, a także posiadać wysokie kompetencje techniczne w zakresie przedmiotowym projektu. O ile drugi i trzeci warunek nie nastręczają problemów - nie brak u nas ludzi inteligentnych i bardzo dobrze wykształconych, o tyle prawdziwym ograniczeniem staje się pierwszy warunek. Według Frame (2001) są tego dwie przyczyny:

- organizacyjna - jeżeli pracownik pracuje w strukturze macierzowej, to nie może poświęcić się całkowicie jednemu projektowi; jego podległość jest takiego rodzaju, że jednocześnie ma obowiązki w ramach kilku projektów jednocześnie (wielozadaniowość);

- psychospołeczna - ludzie nie są robotami i poza pracą zawodową mają swe życie prywatne - naiwnością byłoby zatem oczekiwać od nich stuprocentowego zaangażowania w projekt.

Sprawność i skuteczność działania zespołu projektowego zależą w dużym stopniu od dopasowania do siebie poszczególnych osób wchodzących w ich skład.

Problematyką postępowania, jak stworzyć zespół, który będzie sprawnie realizował zadania przed nim stojące, zajmowało się wielu praktyków i teoretyków, m.in. Maylor (2010), Betta (2012), Trocki i Wyrozębski (2015). Była ona przedmiotem wielu konferencji organizowanych między innymi przez IPMA i PMI. Niewątpliwe duże znaczenie ma pierwsze spotkanie członków zespołu z kierownikiem. Od jego przebiegu i wstępnych ustaleń zależy w dużej mierze powodzenie podczas pracy zespołu. Postawiony cel projektu musi być jasny dla wszystkich, jak również rola, jaką odgrywać będzie każdy członek grupy w realizacji projektu. Kierownik projektu powinien również przedyskutować wszystkie pojawiające się wątpliwości, aby wszystko było jasne i klarowne przed przystąpieniem do prac nad realizacją projektu.

Budowa zespołu projektowego jest więc procesem ciągłym. Szczególnie jest to istotne przy stosowaniu metodyk zwinnych (agilowych). Możemy powiedzieć, iż zebranie ludzi, aby wspólnie pracowali, to za mało, by tworzyli zgrany zespół chcący osiągnąć wspólny cel. Budowanie zespołu jest nierozłączne z procesem realizacji prac projektowych. Dlatego aby stworzyć dobry zespół projektowy, jak pisze Pawlak (2006), należy:

- ciągle doskonalić plan personalny dotyczący zbudowania zespołu i jego działania,

- organizować cykliczne i okazyjne spotkania zespołu,

- wyjaśnić misję zespołu, jego cele i role,

- kierować zespołem w sposób partycypacyjny i w miarę możliwości w sposób akceptowany przez wszystkich,

- włączać zespół w analizę sytuacji i rozwiązywanie problemów,

- ufać aktywnym i efektywnym członkom zespołu i innym współpracownikom, 
- zapewnić efektywność i produktywność zespołu,

- odbierać informacje zwrotne płynące od członków zespołu,

- integrować, koordynować, wspierać i gwarantować przepływ informacji,

- utrzymywać efektywną komunikację.

Właściwie skompletowany zespół projektowy to duże zmniejszenie stopnia ryzyka w realizacji projektu nie tylko informatycznego. Kierownik projektu dąży do dobrania członków grupy, aby współpracowali ze sobą, dochodząc do postawionego na samym początku celu.

Stwierdzenia Chrościckiego (2000) potwierdzają się w praktyce, że w budowie zespołu realizatorów projektu najważniejszą rolę odgrywają:

- uświadomienie wspólnoty celów,

- moc synergii zespołu,

- postawa przełożonego w stosunku do podwładnego, która stanowi czynnik sprzyjający pracy zespołowej,

- budowanie tożsamości zespołu,

- rozluźniające zabiegi socjotechniczne, takie jak zaproponowanie zdjęcia marynarek, rozluźnienia krawatów, przejście na ty to klasyczne sposoby przełamywania pierwszych lodów.

Zespół podlega ciągłemu procesowi zmian, najczęściej przechodzi zgodnie z teorią zwaną ORMING ${ }^{2}$ przez kolejne fazy zmian (por. Tuckman, 1965; Lenta, 2005). Są to:

1. Forming (faza nawiązywania bliższego kontaktu). Uczestnicy projektu poznają się, próbują się wybadać, nawiązywać kontakty, oceniać innych. Uwaga wszystkich skupiona jest na osobie mającej największe osiągnięcia bądź na kierowniku zespołu projektu.

2. Storming (faza pozycjonowania się). Na pierwszym planie znajduje się wyjaśnienie i doprecyzowanie celów, ról, swobody działania poszczególnych osób w zespole projektowym. Próby promowania siebie w zespole kolidują ze staraniami o osiągnięcie konsensusu. Zarówno poszczególni pracownicy, jak i zawiązane koalicje „testują”, jak daleko mogą się posunąć członkowie zespołu i jak zareaguje kierownictwo projektu.

3. Norming (faza organizacji). Na bazie wyjaśnionych zgodnie celów omawiany jest między członkami zespołu sposób postępowania, techniki, funkcje i system komunikacji. Zespół stwarza plan pracy grupy, który umożliwia orientację i kontrolę.Wyniki i zadania są regularnie otwarcie przedstawiane.

4. Performing (faza podejmowania zadań). Zespół w tym momencie jest zdolny podjąć pracę. Cele, sposób postępowania i wzajemne relacje są wyjaśnione, role i funkcje są rozdzielone. Może rozwijać się kreatywność. Ewentualne zakłócenia są dostrzegane i opracowywane tak, aby zespół mógł bez przeszkód działać. W zespole panuje atmosfera kooperacji.

2 B.W. Tuckman w 1965 roku opracował teorię zwaną ORMING, która zakłada, że zespoły przechodzą fazy rozwoju podobne do naturalnego cyklu życia (nazwa teorii wywodzi się od cząstki ,,-orming" powtarzającej się w nazwie każdego etapu cyklu: forming, storming, norming, perforing). W 1977 r. dodał on jeszcze piąty element cyklu adjourning/odroczenie. 
Zachowanie i rola kierowników projektu są bardzo różne. Trudno w tym zakresie przedstawić rekomendacje. Prace autora w tym zakresie są wciąż realizowane. Przedstawione fazy procesu integracji zespołu projektowego nie są procesem ciągłego rozwoju. W każdym momencie zespół może napotkać trudności, które doprowadzą do zaprzestania dotychczasowych prac i zespół będzie zmuszony do ponownego zorganizowania się. Należy jednak zwrócić uwagę na właściwą realizację fazy, która określna jest mianem forming -faza nawiązywania bliższego kontaktu. Do tego, aby zespół projektowy mógł właściwie (ilościowo, jakościowo, kosztowo i czasowo) realizować swoje zadania, jego członkowie muszą być zmotywowani. Motywacja jest siłą napędową grupy i powoduje jej konsolidację. Ten ciekawy problem został tu tylko zasygnalizowany i ze względu na ograniczoność miejsca nie został szerzej zaprezentowany.

\section{Podsumowanie}

Skuteczność i efektywność realizowanych projektów według oceny dotrzymania ich funkcjonalności, zgodności z harmonogramem i założonym budżetem w roku 2010 zakończyła się w 37\% sukcesem (Standish Group, The CHAOS Manifesto, 2011). Podobne wyniki uzyskujemy, analizując raport z bazą danych według ISBSG13 (2013). Baza ta zawiera historyczne dane o zakończonych inicjatywach informatycznych pochodzących od wielu instytucji publicznych i prywatnych, działających w różnych gałęziach przemysłu i administracji, dotyczących zarówno wytworzeniu nowego oprogramowania, jak i modyfikacji istniejącego. Wielkości te są podważane ze względu na brak dostępu do danych źródłowych. Badania Czarnackiej-Chrobot (2013) z kolei wykazały, iż $48 \%$ projektów informatycznych przekroczyło czas trwania, a 40\% budżet. Analizę literatury dotyczącej jakościowej oceny wpływu na sukces realizacji projektu przeprowadził Pospieszny (2016). Wymienione zostały takie przyczyny braku sukcesu jak między innymi: brak komunikacji, nierealistyczny harmonogram, złożoność systemów, braki w klasyfikacji, niska jakość pracy. Mimo że bezpośrednio nie wymieniono odpowiedzialności kierownika projektu, to jednak są to czynniki, na które wpływ ma kierownik projektu. Dlatego też zgodnie z przyjętymi założeniami uważamy, iż skuteczny i efektywny kierownik projektu informatycznego powinien posiadać cały szereg cech, które pozwolą go określić terminem twórczy. Powinien on stale absorbować nową wiedzę i umieć ją przekazywać swoim współpracownikom. Problematyka podjęta w przedstawianym artykule jest niezmiernie szeroka i zdajemy sobie sprawę z konieczności stałego jej poszerzania.

\section{Literatura}

Betta, J. (2012). Zarządzanie wiedzą: istotny czynnik motywowania interesariuszy projektu. Gdańsk: Materiały XIII konferencji Project Managerów.

Chrościcki, Z. (2000). Zarządzanie projektami-zespołami zadaniowymi. Warszawa: C.H. Beck.

Czarnacka-Chrobot, B. (2013). Effectiveness of Business Software Systems Development and Enhancement Projects versus Work Effort Estimation Methods. International Journal of Social, Management, Economics and Business Engineering, 7, 9, 1329-1336.

Frame, J. D.(2001). Zarządzanie projektami w organizacji. Warszawa: WIG-PRESS. 
Gregorczyk, S., Grucza, B., Ogonek, K., Wachowiak, P. (2004). Kierowanie zespolem projektowym. Warszawa: Centrum Doradztwa i Teleinformatyki, DIFI Sp. z o.o.

Jabłoński, M. (2009). Klasyczne podejście w identyfikacji funkcji kierowniczych. Organizacja i Kierowanie, 4.

Kieżun, W. (1999). Sprawne zarzadzanie organizacja. Warszawa: Wydawnictwo SGH.

Kisielnicki, J. (2013). Zarzadzanie projektami badawczo-rozwojowymi. Warszawa: Wolters Kluwer.

Krzakiewicz, K., Cyfert, S. (2012). Przywódcy sensualni w procesie Zarządzania. Materiały z konferencji profesorów nauk zarządzania Polski i Kazachstanu. Astama..

Lent, B. (2005). Zarzadzanie procesami prowadzenia projektów. Informatyka i telekomunikacja. Warszawa: Centrum Doradztwa i Teleinformatyki, DIFI sp. z o.o.

Maylor, H.(2010). Project Management. Boston, N-Y: McGraw Hill.

Merton, R.K. (1985). Teoria socjologiczna i struktura społeczna. Warszawa: Wydawnictwo naukowe PWN.

Mintzberg, H. (1994). The Rise and Fall of Strategic Planning: Reconceiving the Roles for Planning, Plans. New York: Free Press.

International Software Benchmarking Standards Group (2013). ISBSG Repository Data Release 12 - Field Descriptions.

Pawlak, M. (2006). Zarzadzanie projektami. Warszawa: Wydawnictwo Naukowe PWN.

Pospieszny, P. (2016). Zastosowanie technik eksploracji danych do estymacji pracochtonności i czasu trwania projektów informatycznych. Warszawa: Szkoła Główna Handlowa. Kolegium Analiz Ekonomicznych. Instytut Informatyki i Gospodarki Cyfrowej.

Romanowska, M. (2001). Podstawy organizacji i kierowania. Warszawa: Difin.

Standish Group (2011). The CHAOS Manifesto. The Standish Group International. EUA.

Schelle, H., Ottman, R., Pfeiffer, A., (2006). Project Manager. Nurenberg: GPM - Deutsche Gesellschaft fur Projektmanagement.

Szaban, J.(2011). Zarzadzanie zespołem ludzkim w biznesie i administracji publicznej. Warszawa: Difin.

Trocki, M., Wyrozębski, P. (2015). Planowanie przebiegu projektów. Warszawa: Oficyna Wydawnicza SGH.

Tuckman, B.W. (1965). Developmental sequence in small groups. Psychological Bulletin, 63, 384-399. The article was reprinted in Group Facilitation (2001): A Research and Applications Journal, Number 3.

FORMING - STORMING - NORMING - PERFORMING (2016). Pobrane z: http://www.teambuilding.co.uk/Forming-Storming-Norming-Performing.html (15.05 2016).

\section{INFORMATION TECHNOLOGY (IT) PROJECT MANAGER AND HIS ROLE IN THE PROJECT}

\footnotetext{
KEYWORDS $\mid$ IT project management, project manager, project method

ABSTRACT Article presents selected problems related to an analysis of the IT project manager's role. Goal of the article is to identify a set of requirements that should be addressed to a potential IT project manager. It has been assumed that a project manager of IT projects should be a manager and a creator who delivers a unique work, which is the IT project. Requirements have been based on the literature analysis, own research in big enterprises and the opinion of postgraduates and MBA students. Additionally the article presents a proposal of future research.
} 